\title{
Habitat preferences of two deep-diving cetacean species in the northern Ligurian Sea
}

\author{
Paola Tepsich ${ }^{1,2, *}$, Massimiliano Rosso ${ }^{1}$, Patrick N. Halpin ${ }^{3,4}$, Aurélie Moulins ${ }^{1}$ \\ ${ }^{1}$ CIMA Research Foundation, via Magliotto 2, 17100 Savona, Italy \\ ${ }^{2}$ DIBRIS, Università degli studi di Genova, viale Causa 13, 16145 Genova, Italy \\ ${ }^{3}$ Duke University Marine Laboratory, Beaufort, North Carolina 28516, USA \\ ${ }^{4}$ Nicholas School of the Environment, Duke University, Durham, North Carolina 27708-0328, USA
}

\begin{abstract}
We used generalized additive models (GAMs) as exploratory habitat models for describing the distribution of 2 deep-diving species, Cuvier's beaked whale Ziphius cavirostris Cuvier, 1823 and sperm whale Physeter catodon Linnaeus, 1758, in the Pelagos Sanctuary (northwestern Mediterranean). We analyzed data collected from research surveys and whale-watching activities during summer months from 2004 to 2007. The dataset encompassed 147 Cuvier's beaked whale sightings and 52 sperm whale sightings. We defined and applied a post hoc workflow to the data, to minimize false absence bias arising from the unique ecology of the species and the lack of a dedicated sampling design. We calculated a novel topographic predictor, distance from the canyon axis, as a covariate for use in the habitat model. Given the complex topography of the area, the analysis was performed on a high-resolution spatial grid $(1 \mathrm{~km})$. Our methods allowed effective use of the non-dedicated sampling dataset for building habitat models of elusive and cryptic species (Cuvier's beaked whale final model sensitivity $=0.88$ and specificity $=0.84$; sperm whale final model sensitivity $=0.65$ and specificity $=0.77$ ). The GAM results confirmed the preference for submarine canyons for both species and also highlighted the importance of the deeper portion of the Ligurian basin, especially for Cuvier's beaked whale. Habitat overlap nevertheless is resolved by a well-defined spatial partitioning of the area, with sperm whale occupying the western part and Cuvier's beaked whale the central and eastern parts.
\end{abstract}

KEY WORDS: Cuvier's beaked whale $\cdot$ Sperm whale $\cdot$ GAM $\cdot$ Habitat modeling $\cdot$ Northwestern Mediterranean Sea

Resale or republication not permitted without written consent of the publisher

\section{INTRODUCTION}

Species habitat models are widely used for conservation issues, such as planning protected areas, investigating population trends, assessing animal abundance or evaluating the impact of climate change and human activities. Together with the number of applications, the variety of modeling methods is also increasing (Elith et al. 2006). Generally, statistical methods can be divided into 2 groups, based on the quality of species data: presence/ absence methods (i.e. generalised linear/additive models, classification-regression tree analyses, arti- ficial neural networks) and presence-only methods (i.e. Ecological Niche Factor Analysis, Bioclim and Domain) (Guisan \& Zimmermann 2000, Brotons et al. 2004).

Presence/absence methods are recognized to have more explanatory and predictive power than presence-only methods (Hirzel et al. 2001, Brotons et al. 2004), but their performance is highly dependent on the accuracy of absence data. The non-detection of a species while present (false-absence) can occur either by a missed detection or by a temporary absence of the species. When dealing with mobile, rare, or difficult-to-detect species, the false-absence 
bias is very likely to affect the dataset. This a crucial issue in habitat modeling, as the false-absence bias strongly affects model interpretation and accuracy (Gu \& Swihart 2004).

Cuvier's beaked whale Ziphius cavirostris Cuvier, 1823 and sperm whale Physeter catodon Linnaeus, 1758 are deep-diving cetaceans; both species perform deep and long dives which make them difficult to sight at sea (Tyack et al. 2006). In addition to preforming long dives, the Cuvier's beaked whale is also inconspicuous at the surface and is considered to avoid vessels (Heyning 1989). As a consequence, collecting accurate presence/absence data on these species usually requires dedicated surveys involving different techniques (i.e. coupling acoustic and visual surveys, tagging), as standard visual protocols might not be effective (Barlow \& Taylor 2005). The constraints on dedicated studies, particularly the amount of time or expense required to perform the surveys, often result in small sample sizes, with possible consequences on the accuracy of habitat models (Stockwell \& Peterson 2002). Indeed, the use of non-dedicated platforms and, in particular, whale-watching vessels for collecting cetacean data at sea is becoming broadly recognized as a valuable supplement to dedicated surveys (Evans \& Hammond 2004, Redfern et al. 2006). While the use of non-dedicated platforms may result in wider datasets, a well thought-out methodology is still essential for addressing falseabsence bias in the habitat modeling of such cryptic and elusive species.

Both species are regularly sighted in the Mediterranean Sea (Notarbartolo di Sciara 2002). Within the Mediterranean basin, the area of the Pelagos Sanctuary, which covers $87000 \mathrm{~km}^{2}$ in the northwestern Mediterranean, encompassing the Ligurian Sea and parts of the Corsican and Tyrrhenian Seas (Notarbartolo di Sciara et al. 2008), plays a crucial role in the ecology and natural history of these 2 species. Here, 2 key areas for Cuvier's beaked whale distribution are present: one in the NW Ligurian Sea (MacLeod \& Mitchell 2006) and one in the northern Tyrrhenian Sea (Gannier \& Epinat 2008). The Pelagos Sanctury is also an important crossroad for intra-Mediterranean movements of male sperm whales (Frantzis et al. 2011).

Cuvier's beaked whale and sperm whale belong to the same guild: they share a similar feeding ecology with both being primarily teutophagous (Blanco \& Raga 2000, Praca \& Gannier 2007). In the Pelagos Sanctuary, Cuvier's beaked whale exploits the upper and lower slopes along the Ligurian-Provençal coast, at depths ranging from 1000 to $2500 \mathrm{~m}$ (Azzellino et al. 2008, Moulins et al. 2008), showing preference for areas with complex topography (Moulins et al. 2007, Gannier \& Epinat 2008, Azzellino et al. 2012). Similar habitat preferences have been found for the sperm whale, whose preferred habitat lies in the canyons in the slope area (Gannier et al. 2002, Moulins et al. 2008, Praca et al. 2009, Azzellino et al. 2012). Gannier \& Praca (2007) also described a preferred habitat in oceanic waters for the sperm whale. Partial habitat overlap thus occurs among the 2 species, especially in the canyon areas. Submarine canyons are characterized by complicated patterns of hydrography, flow, and sediment transport and accumulation. Acting as a connecting corridor between continental shelf areas and the deep-sea, they play a major role in enhancing oceanographic processes and enriching the deep-sea food web (Canals et al. 2006, De Leo et al. 2010). As a consequence, submarine canyons are widely recognized as hotspots in cetacean distributions (Hooker et al. 1999, Mussi et al. 2001, Moulins et al. 2008). Previous interspecific comparisons suggest that a spatial (Moulins et al. 2008) or temporal (Azzellino et al. 2008) segregation may facilitate the coexistence of the 2 species in canyons. Difficulties in effectively modeling the habitat preferences of the 2 species arise from false-absence bias and from the complexity of the topography that usually characterizes their preferred habitat.

In this study we followed a 3-step process in order to analyze the habitat of deep divers in the Pelagos Sanctuary. We used a large dataset collected from whale-watching vessels and a research vessel operating in the northern Ligurian Sea from 2004 to 2007. First, because the target species are rare and difficult to detect (when using only visual methods), we defined and applied a rigid post hoc workflow for the determination of absence units. Second, we defined a fine resolution grid to characterize the topography of the area, building a specific topographic descriptor for submarine canyons. In the third step, we used presence/absence methods and, in particular, generalized additive models (GAMs) (Hastie \& Tibshirani 1986) to investigate the habitat preferences of the 2 species.

\section{MATERIALS AND METHODS}

\section{Study area}

In 2001 a protected area (the Pelagos Sanctuary) dedicated to Mediterranean marine mammals was established, as the result of an international agree- 
ment between Italy, France and Monaco. Currently the Pelagos Sanctuary is the largest Special Protected Area of Mediterranean Interest (SPAMI) and the only pelagic SPAMI. The study area is located in the northern Ligurian Sea, in the northern part of the Pelagos Sanctuary, and extends from approximately $7^{\circ} 30^{\prime}$ to $9^{\circ} 30^{\prime} \mathrm{E}$ and from Genoa south to $43^{\circ} 20^{\prime} \mathrm{N}$ (Fig. 1), encompassing an area of approximately $7000 \mathrm{~km}^{2}$. The study area is located in a region characterized by very complex bottom topography. The continental shelf is narrow and presents a steep slope, cut by several submarine canyons (De Leo et al. 2010). Among these is the large Genoa Canyon,

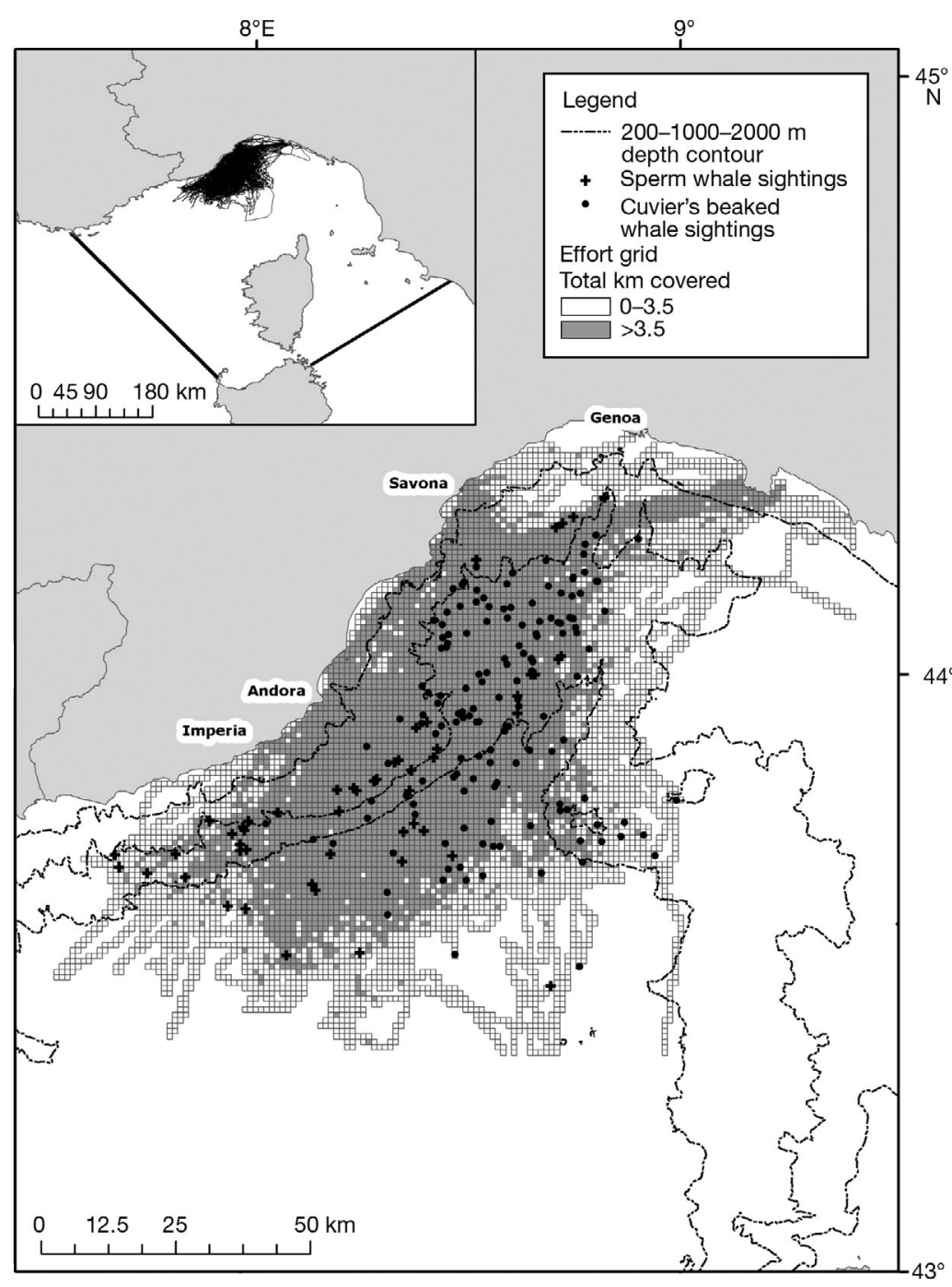

Fig. 1. Study area location inside the Pelagos Sanctuary is shown in the upper left-hand box (black lines are vessel track lines). The final survey effort grid is represented by the grey cells (potential-absence cells), while the white cells were surveyed for $<3.5 \mathrm{~km}$ throughout the study period. Cuvier's beaked whale (Ziphius cavirostris, $\bullet$ ) and sperm whale (Physeter catodon, +) sightings are also shown, locating presence cells which is formed by a system of 2 submarine canyons, corresponding to the 2 rivers that flow into the sea at Genoa, the Polcevera and the Bisagno. Southeast of the mouth of the canyon is also a system of 2 seamounts (Fig. 2).

Though the study area represents $<10 \%$ of the overall width of the Pelagos Sanctuary and, consequently, it cannot be considered representative of the whole area, it lies in the most impacted area. The main commercial ports of the Ligurian Sea are located here, and, as a consequence, all main commercial routes end or begin from this region. Marine traffic as well as environmental and noise pollution in this area are at some of the highest levels within the entire Mediterranean basin (LMIU 2008). Though this study is area specific, it is dedicated to an area requiring effective conservation measures.

\section{Cetacean data}

Cetacean observation data used in this paper come from 2 different datasets. The first dataset was collected on board whale-watching vessels operating in the Ligurian Sea from 2004 to 2007, from different operators and from April to October each year. These whale-watching vessels had previously been used as nondedicated platforms for carrying out cetacean research (Moulins et al. 2007, 2008). As a consequence, a strict protocol for data collection was already in place and was followed on each vessel.

The second dataset was collected on board the University of Genoa's research vessel from 2004 to 2007. Research surveys were carried out year round, with greater research effort in good weather months (spring and summer). Surveys performed from the vessel did not follow any pre-defined sampling design because the aim of surveys was to maximize the probability of encountering cetaceans.

The same protocol for collecting data was adopted on all the vessels used. When the meteorological conditions allowed for an effective survey (Beaufort sea state $<3$ ), the on-effort monitoring activity was conducted at a speed of approximately 10 to $15 \mathrm{~km} \mathrm{~h}^{-1}$. At least 3 trained 


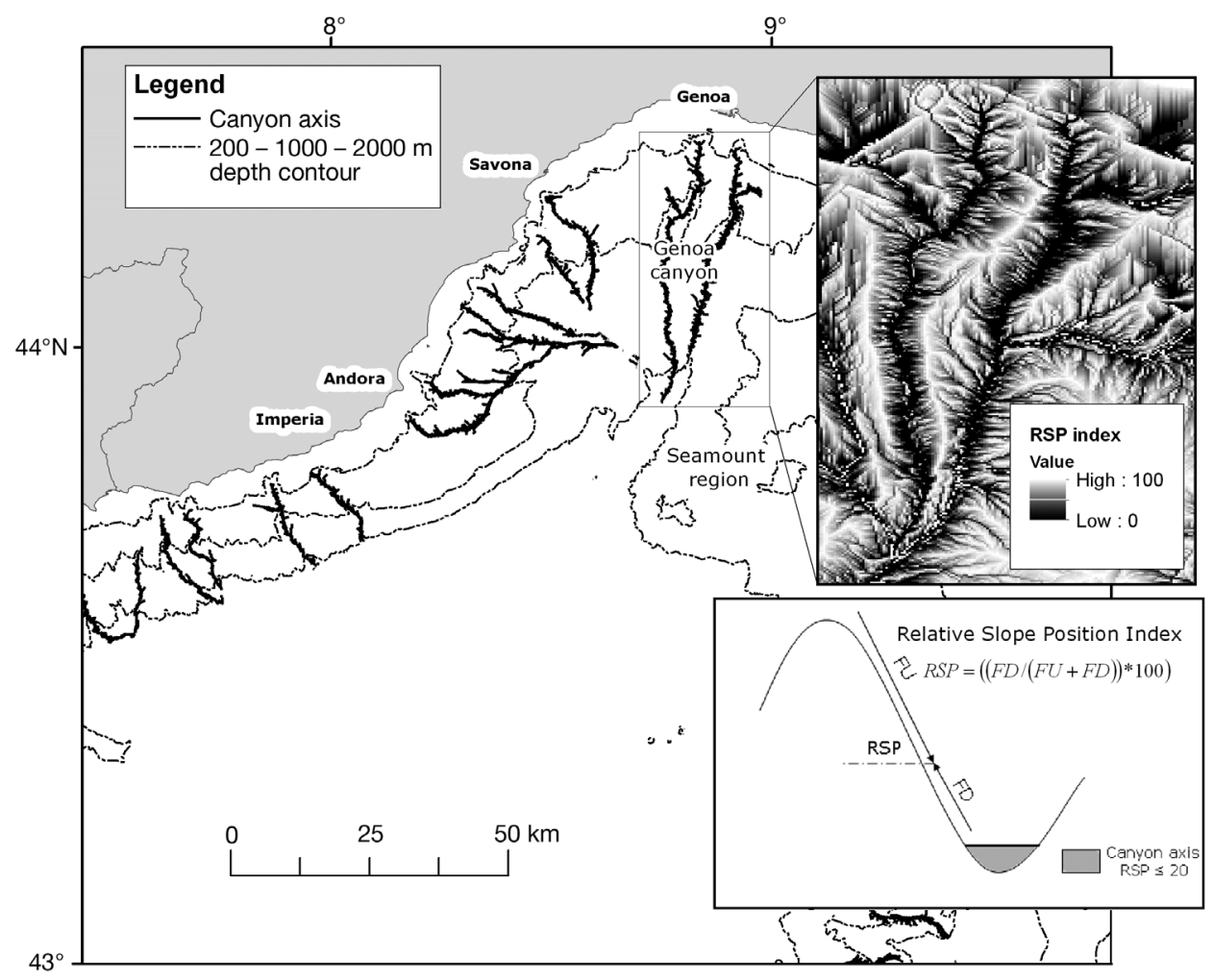

Fig. 2. Canyon axes in the study area, obtained by computation of the relative slope position (RSP) index. Panels on the right show a close up of the Genoa Canyon and the corresponding RSP values (upper panel) and a scheme illustrating the RSP index (lower panel) observers were placed on the upper deck to scan $360^{\circ}$ around the vessel with and without binoculars. The elevation of the upper deck was variable according to the dimensions of the vessels, and ranged from 4 to $7.5 \mathrm{~m}$ above sea level. On each vessel, observers rotated quadrants every $30 \mathrm{~min}$ to avoid fatigue. Effort data were recorded throughout the trip, using Logger2000 software or a portable GPS. Weather conditions were recorded every $30 \mathrm{~min}$. When cetaceans were spotted, they were approached by the vessel to allow for exact identification of the species, a count of the number of individuals, and observation of any peculiar behavior.

Whale-watching vessels departed from 4 harbors (Genoa, Savona, Imperia, Andora) along the western Ligurian coast and, consequently, they had slightly different search-effort areas: the centraleastern part of the study area when departing from Genoa or Savona and the western part when departing from Imperia or Andora). The research vessel departed from Savona, and its effort was more concentrated in the central part of the study area (Fig. 1). In order to achieve a uniform coverage of the study area, and given the similarities in the survey strategy and temporal distributions of research effort, the 2 datasets were analyzed together as a single dataset.

\section{Environmental variables}

The environmental variables used to model species habitat are the ones commonly used to describe Cuvier's beaked whale and sperm whale distributions: depth, distance from the $200 \mathrm{~m}$ contour (corresponding to the shelf break) and slope (Cañadas et al. 2002, Azzellino et al. 2008, Praca et al. 2009). All these variables were derived using ArcGIS 9.2 from a fine-resolution bathymetric grid $(100 \mathrm{~m})$ of the Ligurian Sea kindly provided by IFREMER (Institut français de recherche pour l'exploitation de la mer, France). The bathymetric grid was imported into ArcGIS and projected onto a universal transverse mercator (Zone $32 \mathrm{~N}$ ) coordinate system before deriving the different topographic rasters.

For the definition of submarine canyons, the canyon axis was identified by computing a relative slope position index (RSP) (Parker 1982, Wilds 1996, Weiss 2001, Dunn \& Halpin 2009). The RSP for each cell expresses the percent distance of the considered pixel from the bottom of the slope; cells representing the bottom of the slope then have the value $0 \%$, while cells representing the ridge top have the value $100 \%$. The bottom and the top of the slope were identified using the hydrological tools in ArcGIS Spatial Analyst. In particular, first the flow-direction tool 
was used to identify the direction of steepest descent from each cell. Then using the flow-accumulation function, we computed the total number of neighboring cells that flow to each grid cell. The bottom of the slope was identified by all those cells with at least 3000 cells of accumulation. Finally, using the flowlength tool (with downstream option, FD), we calculated for each cell the distance from the bottom of the slope. For the top of the slope, we identified cells showing a difference from the mean elevation of neighboring cells $>50 \mathrm{~m}$ within a rectangle window $\sim 1000 \mathrm{~km}^{2}$ wide. The flow-length tool (upstream option, FU) was then used to measure distance from these cells. The RSP was subsequently calculated following the formula:

$$
\mathrm{RSP}=[\mathrm{FD} /(\mathrm{FU}+\mathrm{FD})] \times 100
$$

All cells with a RSP $\leq 20$ were classified as the canyon axis, while all other pixels were set as no data (Fig. 2). For the definition of the thresholds chosen in the canyon axis identification process, we started from default thresholds proposed by the software, then adjusted these in accordance with our knowledge of the sea bottom topography in the study area (Weiss 2001, Qin et al. 2006). Finally, a raster of distances from the nearest canyon axis was calculated using the Euclidean Distance tool in ArcGIS.

Previous research carried out in the Pelagos Sanctuary revealed a longitudinal segregation between the 2 species, with a higher presence of sperm whale in the northwestern part of the area, while Cuvier's beaked whale is more common in the Gulf of Genoa area (Gannier et al. 2002, Moulins et al. 2008). These opposite longitudinal gradients in the distribution of the 2 species might allow the spatial differentiation of habitat. In order to model this gradient, we included longitude as a variable in the habitat model (Certain 2008). Spatial variables, such as longitude and latitude, though not directly related to the biology or ecology of the species, nor to their prey, can be considered proxies for variables that cannot be measured, such as sub-regional differences in species distribution (Ashe et al. 2010, Pirotta et al. 2011, Spyrakos et al. 2011, Bonizzoni et al. 2013). The variables used as predictors are summarized in Table 1.

Oceanographic variables have not been included in the habitat modeling for several reasons. First, as inter-annual differences in species distribution was not the aim of this study, cetacean distribution data for the whole study period were pooled. Consequently, oceanographic descriptors should be used at the same temporal scale, resulting in multiyear aver- ages. The area is characterized by a strong interannual variability in oceanographic parameters (Astraldi et al. 1994, Fusco et al. 2003, Picco et al. 2010); the use of multiyear averages might confound the relationship between predictors and species distribution. Moreover, the fact that sperm whales and Cuvier's beaked whales are preferentially found in sub-marine canyon regions may be more dependent on the deep circulation occurring in the canyons than on the environmental variability of the thermal front or of the upper layers (Azzellino et al. 2008).

\section{Data processing}

We set the analysis grid at a $1 \mathrm{~km}^{2}$ resolution. This fine resolution was chosen in order to better inspect the role of the complex topography of the area. To ensure temporal consistency in the analysis, only data collected during the summer season (from June to September) were included.

All vessel track-lines, as well as all sighting data of the 2 target species, were plotted onto the $1 \mathrm{~km}^{2}$ square cell grid. We considered each cell containing a sighting to be a presence cell. Presence cells were determined separately for Cuvier's beaked whales and sperm whales.

The first step in defining absence cells required the exclusion of poorly surveyed cells. As a consequence, the total number of kilometers covered on effort within each cell was computed, and only cells containing at least $3.5 \mathrm{~km}$ of on-effort survey distance, but not containing sightings, were considered potential-absence cells (Fig. 1). The $3.5 \mathrm{~km}$ threshold was fixed using the Jenks natural breaks classification method (Jenks 1967) in ArcGIS, on the overall sum of kilometers surveyed in each cell.

The second step involved the assessment of the reliability of the potential-absence cells. Considering the feeding behavior of the 2 species and the fine res-

Table 1. Topographic variables used as predictors in habitat models, with units and abbreviations used in formulas and graphs

\begin{tabular}{|lll|}
\hline Topographic variable & Unit & Abbrev. \\
\hline $\begin{array}{l}\text { Depth } \\
\begin{array}{c}\text { Distance from } \\
\text { shelfbreak }\end{array}\end{array}$ & Meter & DEPTH \\
$\begin{array}{l}\text { Distance from } \\
\text { canyon axis }\end{array}$ & Meter & DIST_200 \\
$\begin{array}{l}\text { Slope } \\
\text { Longitude }\end{array}$ & Degree & SLOPE \\
\hline
\end{tabular}


olution of the grid used, potential-absence cells in close proximity to presence cells are more likely to be false-absence cells. Thus, we decided to apply a circular buffer to each sighting position; this occupancy buffer accounts for the assumption that once the whale has been sighted it has occupied (or it will occupy) a wider area around the actual sighting position. The size of the buffer was selected separately for each species. Four different buffer sizes were tested: 2, 4, 6 and $8 \mathrm{~km}$ radii. Each cell of the buffered presence/absence grid was given a value for each of the environmental variables described above. For longitude, the longitude of the center of the cell was chosen.

Current knowledge of the 2 target species distributions in the area indicates how both species exploit habitat described by different topographic features (slope and canyon areas, but also oceanic waters). The relationship between species presence and these variables thus is not expected to be linear. Among the several different statistical approaches available for modeling species habitat, GAMs are an appropriate technique to model species which are expected to have complex relationships with environmental variables (Segurado \& Araújo 2004). GAMs allow a data-driven approach by fitting smoothed non-linear functions of explanatory variables without imposing parametric constraints (Hastie \& Tibshirani 1986). As a consequence, GAMs are more flexible and are particularly good at identifying non-linear relationships between species presence and predictor variables.

In order to assess an adequate size for the buffer, a GAM was built first using the entire dataset and then progressively eliminating cells within the different buffers. As the purpose of these GAMs was to assess the ability of the model to discriminate between habitat and non-habitat rather than to inspect the ecological influence of variables, all variables were included and no spline-fitting knot limit was set.

Five GAMs were built for each species. The optimal buffer size was selected considering the increase in model ability to discriminate between used and non-used habitat, evaluated by the deviance explained by each model. The optimal buffer size was selected when the deviance explained by the model reached at least $50 \%$.

\section{Habitat modeling}

The entire dataset was split in order to allow model evaluation with a dataset different from the one used for model fitting. We randomly selected two-thirds of the original dataset for model construction and used one-third as the model-testing dataset. Then a buffer of the size selected in the first step was applied to all sightings, and all potential-absence cells within the buffer were excluded from the analysis. This process was done separately for each species and separately for the model construction and for the model-testing dataset.

GAMs were fitted using the mgcv package in $\mathrm{R}$ v.2.14.1 following a presence/absence approach. The binary approach was preferred to the density approach (modeling of encounter rates) as the aim was to point out differences in habitat preferences between the 2 species, rather than to predict density and/or map distribution patterns of the 2 species throughout the survey area. Moreover, given the fine spatial resolution used in this study, each presence cell contained only a single sighting. Consequently, transforming presence into a density measure, such as an encounter rate, would result in a biased signal, with cells with less effort having more power but not necessarily reflecting a higher preference of the species towards the cell.

GAMs for each species were fitted using a quasibinomial distribution family with a logit link function in order to account for over-dispersion in the dataset. In order to avoid over-fitting, the spline-fitting process was restricted to 4 knots and a gamma function of 1.4 was applied (Wood 2006). Model selection was conducted using a basis smoothing function that shrinks non-significant terms to 0 degrees of freedom, i.e. thin-plate splines with shrinkage. Covariance between environmental variables was investigated before their inclusion in the habitat modeling processes. Variables showing covariance $>0.8$ were not included in the GAMs. The amount of survey effort in each grid cell was used as a weighting factor in the model, in order to both determine whether all habitat types had been adequately sampled and to further control for the risk of 'false' absences (MacLeod et al. 2008). Output of the final GAM was evaluated following the GAMvelope approach (Torres et al. 2008). We used the zero line on each GAM plot to divide the range of the explanatory variable that had a positive effect (identified as habitat) from the range that had a negative effect (identified as non-habitat) on the response variable. Peaks in the GAM plots indicate preferred habitat.

Model performance was evaluated with confusion matrices that compare the binary predictions to the observed values and report the true and false presences and the true and false absences, thus summa- 
rizing the goodness-of-fit of the model (Fielding \& Bell 1997). To select the appropriate cut-off probability value for building confusion matrices, we used the receiver operating characteristic (or ROC curve) method (library ROCR in $R_{i}$ Sing et al. 2005). Since the goal of the modeling process was to correctly select species habitat, as well as to exclude non-habitat, model evaluation with the model-testing dataset was conducted using the true skill statistic (TSS; Allouche et al. 2006). TSS is computed from 2 measures of model accuracy: model sensitivity (or true positive rate, i.e. the proportion of correctly classified presences) and model specificity (or true negative rate, i.e. the proportion of incorrect presence classifications). These 2 parameters are independent of each other and are also independent of prevalence (the proportion of sites in which the species has been recorded as present).

TSS is expressed by the following formula:

$$
\text { TSS }=\text { sensitivity }+ \text { specificity }-1
$$

TSS ranges from -1 to +1 , with +1 indicating perfect model performance and 0 indicating model performance is not better than a random model.

\section{RESULTS}

A total of 524 daily surveys were conducted in the study area from June to September from 2004 to 2007. On the whole, vessel track lines accounted for $47188 \mathrm{~km}$ distributed in 6988 cells. Cuvier's beaked whale Ziphius cavirostris was sighted 147 times, for a total of 376 individuals; and sperm whale Physeter catodon was sighted 52 times for a total of 68 individuals during the study period. After eliminating poorly surveyed cells, the final grid used for the analysis consisted of 3892 cells for Cuvier's beaked whale (145 presence cells, including 15 in poorly surveyed cells [research effort $<3.5 \mathrm{~km}$ ]) and of 3884 cells for sperm whales (52 presence cells, including 6 in poorly surveyed cells). These datasets were then used to assess the 'occupancy buffer' size.

GAMs built using the entire dataset exhibited very little power to explain species distribution (Table 2). This is likely caused by the overdispersion of data due to false-absence inflation. The $2 \mathrm{~km}$ buffer did not improve model performance. In the case of Cuvier's beaked whale, strong improvement was achieved applying the $4 \mathrm{~km}$ buffer, while, for the sperm whale, a $6 \mathrm{~km}$ buffer was required to reach the fixed threshold of at least $50 \%$ explained deviance (Table 2). Potential-absence cells found within each species buffer were eliminated and not considered for the final GAMs.

\section{Cuvier's beaked whale}

For Cuvier's beaked whale, 95 presence cells and 1141 absence cells were used for model construction. Analysis of covariance among environmental variables showed high covariance between distance from the $200 \mathrm{~m}$ contour (DIST_200) and depth (DEPTH) (0.87). Since DIST_200 also showed strong correlation with the predictor distance from the canyon axis (DIST_CAN) (0.79), the variable DIST 200 was excluded from the model. The final GAM retained all predictor variables and was able to explain $60.5 \%$ of the deviance in data (Table 3 ).

For Cuvier's beaked whale, the habitat highlighted by the GAM was characterized by depths exceeding $600 \mathrm{~m}$ and with a single peak at around $1500 \mathrm{~m}$. The role of canyons as hot spots for this species emerged with a favorable range of DIST_can of up to $10000 \mathrm{~m}$ and a peak at $\sim 5000 \mathrm{~m}$. A non-canyon habitat is also evidenced as a positive effect of this variable, seen at DIST_CAN $>30000 \mathrm{~m}$. The species seemed to prefer flat areas, as a negative effect of slope is seen for SLOPE $>7^{\circ}$. Longitude also showed a clear role in describing species habitat, which is encompassed between 440000 and 500000 m easting, with a clear peak in the central part of the study area. (Fig. 3).

The ROC method was used to select habitat versus non-habitat areas and the optimal cutoff was set to 0.08 . The model-testing dataset consisted of 50 pres-

Table 2. Results of a generic generalized additive model (GAM) fitted applying different buffer sizes to Cuvier's beaked whale Ziphius cavirostris and sperm whale Physeter catodon datasets

\begin{tabular}{|lccc|}
\hline Buffer $(\mathrm{km})$ & $\mathrm{N}$ & $\begin{array}{c}\text { Deviance } \\
\text { explained (\%) }\end{array}$ & $\mathrm{r}^{2}$ \\
\hline \multicolumn{4}{|c}{ Cuvier's beaked whale (2004-2007) } \\
0 & 3892 & 15.2 & 0.0552 \\
2 & 3346 & 19.9 & 0.0853 \\
4 & 2038 & 53.8 & 0.495 \\
6 & 1357 & 90.1 & 0.925 \\
8 & 1031 & 100 & 1 \\
Sperm whale (2004-2007) & & \\
0 & 3884 & 24.7 & 0.0812 \\
2 & 3690 & 28.1 & 0.121 \\
4 & 3003 & 42 & 0.376 \\
6 & 2294 & 57.9 & 0.494 \\
8 & 1666 & 87.4 & 0.89 \\
\hline
\end{tabular}


ence cells and 762 absence cells. When applied to the model-testing dataset, the model correctly predicted 44 of the 50 presence cells and 642 of the 762 absence cells. This model has a sensitivity of 0.88 and a specificity of 0.84 . The TSS value for this model is 0.72 .

\section{Sperm whale}

For sperm whale, 35 presence cells and 1427 absence cells were used for the model construction. Similarly to the Cuvier's beaked whale model fitting process, DIST_ 200 was excluded, being strongly correlated with DEPTH and DIST_CAN. The final GAM for this species also retained all considered variables, but with a lower power, as it was able to explain only $25.7 \%$ of the deviance in the data (Table 4).

Sperm whale habitat is found at depths between 450 and $1500 \mathrm{~m}$, while its preferred habitat is described by a peak at $\sim 800 \mathrm{~m}$ depth. The role of submarine canyons as key habitat areas for the species did not emerge as expected, as species habitat was found at DIST_CAN $>3000 \mathrm{~m}$, with 2 peaks, the first at $10000 \mathrm{~m}$ distance and the second at distances $>30000 \mathrm{~m}$. There was evidence of a clear preference for steep-slope areas, even though a flat seafloor is also selected by the species. Again, we found a clear geographic preference, with a single mode identifying a hot spot in the western part of the study area (LON < 450000$)$, while the central and eastern portions of the study area were classified as non-habitat (Fig. 4).

The dataset used for evaluating model performance consisted of 17 presence cells and 831 absence cells. The optimal cutoff evaluated with the ROC method was 0.02 , and the model correctly predicted 11 out of the 17 presence cells (sensitivity $=0.65$ ) and 636 out of the 831 absence cell (specificity $=0.77$ ). The TSS value for this model is 0.41 .

\section{DISCUSSION}

Despite the establishment in 2002 of Pelagos Sanctuary (Notarbartolo di Sciara et al. 2008), information about species abundance and distribution in the area is still scarce; the conservation status of a Mediterranean subpopulation of 4 out of 8 cetacean species is listed as 'Data Deficient'. While in most regions the very first step towards the identification of cetacean habitat, migration patterns and population structure has largely been based on whalers' logbooks (Jaquet 1996, Gregr et

Table 3. Final generalized additive model (GAM) results for Cuvier's beaked whale Ziphius cavirostris (see Table 1 for variable abbreviations). ${ }^{* * *} \mathrm{p}<0.001$

\begin{tabular}{|c|c|c|c|c|c|c|}
\hline & Estimate & edf & $\mathrm{SE}$ & $t$ & $F$ & $\mathrm{p}$ \\
\hline Intercept & -8.1608 & & 0.4778 & -17.08 & & $<2 \times 10^{-16 * * *}$ \\
\hline \multicolumn{7}{|l|}{ Smoother terms } \\
\hline DEPTH & & 2.852 & & & 91.58 & $<2 \times 10^{-16 * * *}$ \\
\hline DIST_CAN & & 2.948 & & & 11.56 & $1.08 \times 10^{-7 * * *}$ \\
\hline SLOPE & & 2.512 & & & 16.12 & $1.36 \times 10^{-11 * * *}$ \\
\hline LON & & 2.668 & & & 73.76 & $<2 \times 10^{-16 * * *}$ \\
\hline Deviance explain & & $60.5 \%$ & & & & \\
\hline
\end{tabular}
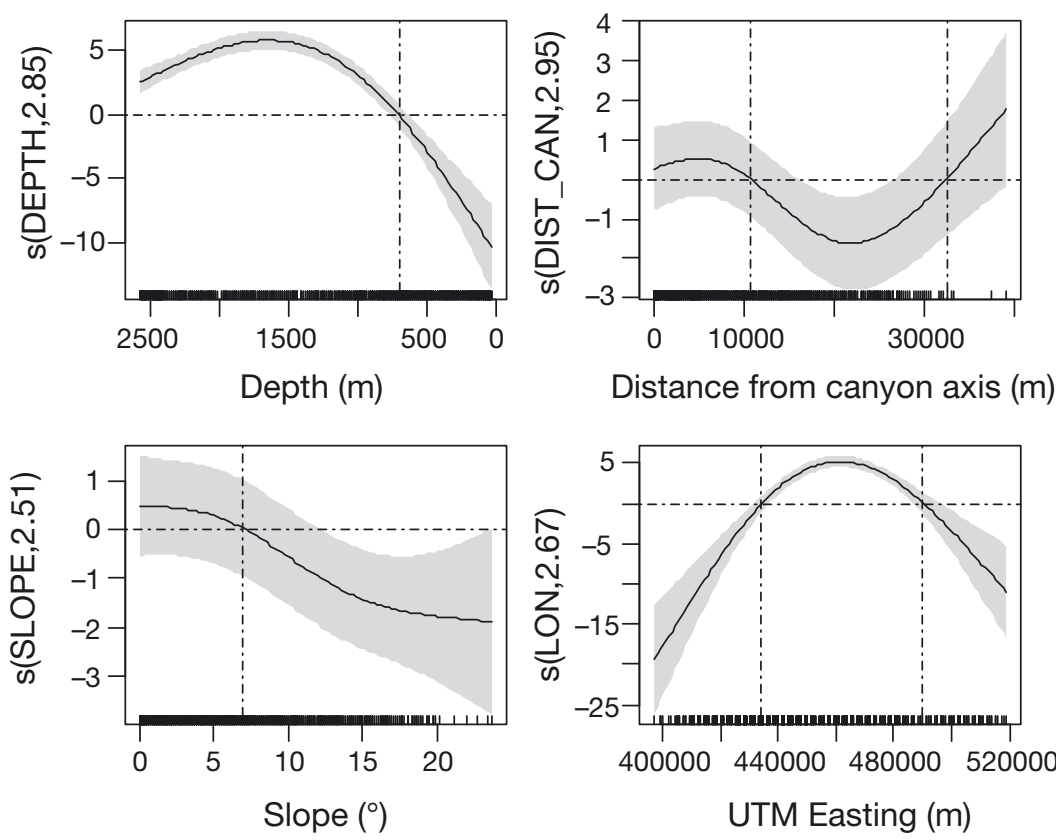

Fig. 3. Generalized additive model (GAM)-predicted smooth splines of the response variable presence/absence of Cuvier's beaked whale Ziphius cavirostris as a function of the explanatory variables (see Table 1). The degrees of freedom for non-linear fits are in parentheses on the $y$-axis. Tick marks above the $x$-axis indicate the distribution of observations (with and without sightings). Shaded area represents the $95 \%$ confidence intervals of the smooth spline functions. Confidence bands include uncertainty about the overall mean (Marra \& Wood 2012). UTM: Universal Transverse Mercator 
Table 4. Final generalized additive model (GAM) results for sperm whale Physeter catodon (see Table 1 for variable abbreviations). ${ }^{* * *} \mathrm{p}<0.001$

\begin{tabular}{|c|c|c|c|c|c|c|}
\hline & Estimate & edf & $\mathrm{SE}$ & $t$ & $F$ & $\mathrm{p}$ \\
\hline Intercept & -4.8532 & & 0.1371 & -35.39 & & $<2 \times 10^{-16 * * *}$ \\
\hline \multicolumn{7}{|c|}{ Smoother terms } \\
\hline DEPTH & & 2.998 & & & 53.785 & $<2 \times 10^{-16 * * *}$ \\
\hline DIST_CAN & & 2.946 & & & 43.668 & $<2 \times 10^{-16 * * *}$ \\
\hline SLOPE & & 2.812 & & & 9.471 & $1.39 \times 10^{-6 * * *}$ \\
\hline LON & & 2.714 & & & 69.950 & $<2 \times 10^{-16 * * *}$ \\
\hline Deviance explaine & led & $25.7 \%$ & & & & \\
\hline
\end{tabular}
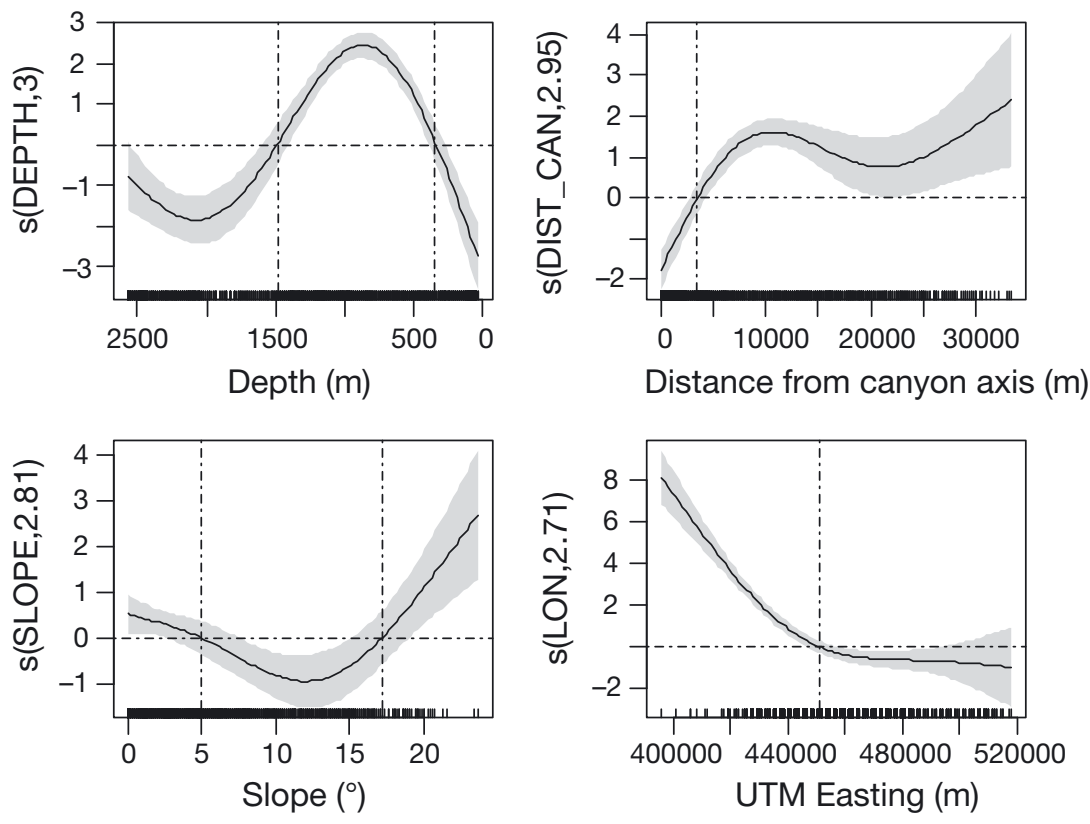

Fig. 4. Generalized additive model (GAM)-predicted smooth splines of the response variable presence/absence of sperm whales Physeter catodon as a function of the explanatory variables (see Table 1). The degrees of freedom for nonlinear fits are in parentheses on the $y$-axis. Tick marks above the $x$-axis indicate the distribution of observations (with and without sightings). The shaded area represents the $95 \%$ confidence intervals of the smooth spline functions. Confidence bands include uncertainty about the overall mean (Marra \& Wood 2012). UTM: Universal Transverse Mercator

al. 2000, Gregr \& Trites 2001), such datasets do not exist for the Mediterranean, where a whaling industry never developed. As a consequence, it has been difficult to assess baselines to develop ad hoc research studies.

On the other hand, the development of a whalewatching industry offers the possibility of obtaining large observation datasets in a relatively short period of time. Many studies demonstrate how these datasets, when collected following an ad hoc protocol and/or analyzed taking into account potential sources of bias, can be a valuable resource for under- standing species distribution. Whalewatching datasets have previously been used to characterize cetacean habitats within the Pelagos Sanctuary (Azzellino et al. 2001, 2008, Moulins et al. 2007).

In this work, we used data collected from several vessels in order to inspect the habitat preferences of 2 deep-diving species, Cuvier's beaked whale Ziphius cavirostris and the sperm whale Physeter catodon. When observing elusive species, the overinflation of false-absence cells, caused by non-detection of the species while the species is actually present, is a common issue. This adds to the effort bias related to the use of datasets not obtained from dedicated surveys. Our methodology is based both on a critical assessment of false-absence bias and an analysis of effort data.

The analysis of the effort data carried out before proceeding with the habitat modeling process allowed for an effective minimization of effort-related biases. Biases associated with the lack of a dedicated survey design, and especially when using whalewatching datasets, may result in intraannual coverage differences, multiple surveys during the day, differences in vessel characteristics, duplicate sightings, or biased effort distribution due to 'whaler behavior' (concentration of effort in specific areas and periods) (Koslovsky 2008).

Though the vessels considered in this analysis operated from April to October, we selected only trips/surveys operated during the summer season (June to September), because this is the season during which both whale-watching and research vessel effort is at a maximum and more regular. This minimizes the differences between whale-watching companies' effort during the year. In analyzing bias from whale-watching vessels, Koslovsky (2008) also highlighted that when multiple surveys are performed during the same day by the same vessel, area and time spent searching for whales differ. In our database we only observed 2 days on which a survey was performed by the same vessel, so we are confident this issue did not affect our analysis. 
When different whale-watching companies operate in the same area they usually co-operate and inform each other about cetacean positions. As a consequence, different datasets may report the same cetacean group sighting. Our cetacean database has been compiled coherently throughout the operating years, allowing corrections, such as elimination of sightings of the same cetacean group by different vessels operating during the same day. Another potential issue is that data were collected on board different vessel types. Vessel characteristics, such as observation deck height and speed affect the sightability of cetacean species. In order to avoid this bias a common protocol was adopted during all trips.

Both the whale-watching vessels and research vessel attempted to maximize the probability of cetacean encounter during trips/surveys (haphazard sampling). As a result, effort is biased by the so-called 'whaler behavior' search method, resulting in effort being more concentrated in areas where cetaceans are expected. The most common species in the area are the striped dolphin and fin whale (Reeves \& Notarbartolo Di Sciara 2006). Fin whale is the main target species for whale-watching activities in the area. Thus, it is unlikely that the search patterns of vessels are biased towards the habitat of deep divers. Moreover, deep-diving species are not considered as attractive by the whale-watching industry, as these whales spend little time at the surface. Sperm whale and Cuvier's beaked whale sightings then can be considered accidental sightings, occurring while searching for other species. In the case of the research vessel, no acoustic device was used to detect sperm whale or Cuvier's beaked whale presence; therefore, the encounter probability is expected to be similar to that of whale-watching vessels.

Our final datasets consisted of 147 sightings of $\mathrm{Cu}$ vier's beaked whale. The large number of sightings recorded using only visual methods seems to indicate that the species is not as elusive to vessels as usually stated for other areas worldwide (Heyning 1989, Barlow \& Taylor 2005). Difficulties in collecting data on Cuvier's beaked whale arise mainly as a result of the short time individuals spend at the surface. Specifically trained observers, together with the adoption of an ad hoc protocol for approaching the animals, maximize the probability of sightings and, consequently, the success of data collection.

Together with improving the detection rate of this species and increasing the number of presence cells in order to effectively model species habitat, we also focused significant attention on the definition of absences. While presence/absence habitat models should be preferred to presence-only models (MacLeod et al. 2008, Praca et al. 2009), their interpretation can be strongly affected by false-absence bias (Gu \& Swihart 2004). We particularly addressed the source of false-absence bias that leads to erroneous classification of habitat cells as non-habitat cells. In the first instance, we excluded from the analysis all cells in which non-detection of the target species could arise from limited survey effort. Secondly, we excluded all cells in close proximity with presence cells. Given the diving duration of both species and the inconspicuous behavior of Cuvier's beaked whale at the surface, considering cells in close proximity with presence cells as absences would likely lead to a misclassification of habitat cells as non-habitat cells. The identification of an occupancy buffer allowed for more controlled fitting of habitat models for both species. In order to verify the appropriate size of the occupancy buffer, we looked at information about the species' horizontal movements. Falcone et al. (2009) measured horizontal movements of Cuvier's beaked whale over the course of a sighting as a straight-line distance between the first and last observed surfacing which ranged from 0.08 to $6.65 \mathrm{~km}$. The occupancy buffer of $4 \mathrm{~km}$ fits within this observed range.

For sperm whales, displacement is usually negatively correlated with feeding success (Whitehead 2003b). In the northwestern Mediterranean Sea, which is recognized as a feeding ground for this species, Drouot et al. (2004) measured a mean horizontal range of 1.3 nautical miles $(\sim 2.4 \mathrm{~km})$ between feeding dive cycles. In the same study, it was observed how foraging animals tend to remain within the same area and follow isobaths, thus moving within the same habitat. This could explain the need for a wider buffer $(8 \mathrm{~km})$ when studying this species.

Submarine canyons are the preferred habitat of many squid species and, consequently, they are a suitable feeding ground, especially for toothed deepdiving cetaceans (Gowans et al. 2000, Ciano \& Huele 2001, Waring et al. 2001, MacLeod \& Mitchell 2006, Moulins et al. 2007, Azzellino et al. 2008). Despite being widely used as an environmental predictor for cetacean presence, no objective identification of canyon spatial boundaries has ever been made. In cetacean habitat analysis, topographic descriptors such as slope and depth (and their means and/or standard deviations) are usually used as proxies for canyon presence as model predictors (Azzellino et al. 2011). Previous attempts to identify canyon areas versus continental shelf areas have been made by enclosing canyons into arbitrary (Kenney \& Winn 1987, Hooker et al. 1999) or topographically defined 
(Waring et al. 2001) boxes. The GIS method implemented in this work identified the centerline axis of the 17 submarine canyons in the study area when compared to official mapping (Migeon et al. 2011) (Fig. 2). Previous attempts to study the influence of canyons on cetacean distributions seldom considered the actual bottom topography, and sightings have been qualitatively assigned to canyon areas (Hooker et al. 1999, Waring et al. 2001, D'Amico et al. 2003). In the northern part of the Pelagos Sanctuary a number of canyons cut through the shelf break; as a consequence, from a qualitative point of view, the entire area might be considered a canyon basin. The GISbased topographic analysis method used for the optimal identification of the canyon axis allowed for a more effective characterization of this kind of habitat. For both species, final GAMs retained all the topographic variables chosen for the analysis, even though some differences in species responses were noted.

For Cuvier's beaked whale the model's ability to capture the variability in the distribution is high ( $60 \%$ deviance explained by the final model). Depth preferences well reflect the results obtained both in the same study area (Moulins et al. 2007, Azzellino et al. 2008) and elsewhere in the Pelagos Sanctuary (Gannier \& Epinat 2008). A clear preference for the canyon habitat is exhibited, and a core habitat area is indicated in the central part of the study area. This central habitat area corresponds to the Genoa Valley, where the Genoa Canyon, as well as the smaller western coast canyons, converge. The Cuvier's beaked whale GAM also confirms the existence of a second habitat for this species, in deeper waters and not closely related to canyon axes. It is also possible that the 2 habitats are exploited by the species at different times of the year. Seasonal or even monthly analyses should be done to address this question.

Final model performance was high even when compared with the model-testing dataset. This result may be considered an indication of residency of the species in the area. Photo-identification studies conducted in the area confirm a high fidelity to the Genoa area of a population of about 100 individuals (Rosso et al. 2011). The sperm whale model generally performed less well than that for Cuvier's beaked whale, with the best model explaining only $25.7 \%$ of the deviance. Lower performance of the habitat models for sperm whale might have been due to the smaller dataset size, which must be taken into account as a study constraint.

Sperm whale habitat is generally located in the western part of the study area, while no preference seemed to occur for the central or eastern region.
Other studies identified an important feeding ground for this species in the western part of the Pelagos Sanctuary, in an area that is rich in submarine canyons; this area lies west of our study area (Gannier et al. 2012). Though our GAM results show that species habitat is highly connected with the steepest part of the continental slope, the role of submarine canyons did not emerge as expected. When modeling sperm whale habitat in the northwestern Mediterranean, other authors have noted that the species seems to have 2 different distribution patterns: one closely related to the topography of the sea-bottom in shallower waters and one in the deeper pelagic domain (Gordon et al. 2000, Gannier et al. 2002). These 2 different habitats do also emerge from our analysis, as evidenced by the 2 peaks in the smooth splines for DIST_CAN (Fig. 4): one at 10000 m distance and one at distances $>30000 \mathrm{~m}$. In the deeper domain the species is thought to feed on pelagic cephalopods and its distribution is thought to be more influenced by oceanographic features than by topographic ones (Gannier \& Praca 2007). The sole use of topographic features in our habitat model may not properly characterize the additional oceanographic influence on the species distribution. This could explain the weaker performance of the GAM with this species.

In contrast, it is also interesting to note that the habitat model for Cuvier's beaked whale performs well even if sea-surface oceanographic variables are not considered; these might then play a secondary role in shaping this species' distribution. From a conservation point of view, this highlights the possibility that it may be more efficient to map conservation areas for Cuvier's beaked whale than for sperm whale, as the latter species may require dynamic mapping.

When evaluated with the model-testing dataset, the model showed lower sensitivity and specificity. Indeed, though the shape of the smooth spline shows an inflection point at around $2000 \mathrm{~m}$ from which the function starts tending towards positive values, our model failed to detect species habitat in oceanic waters. Moreover, lower TSS values for the sperm whale may also arise due to the free-ranging behavior of the species, in contrast with the more resident Cuvier's beaked whale.

Differences in habitat use among sperm whales and beaked whales have been noted elsewhere (Whitehead et al. 1997, Waring et al. 2001). Whitehead (2003a) also assessed how sperm whale feeding habits are more differentiated than those of beaked whales. When considering feeding habits, sperm whales can be considered generalists, while Cuvier's 
beaked whales should be considered specialists. Feeding habits also have an influence on movement patterns (or vice versa), with sperm whales being much more free ranging than Cuvier's beaked whales (Whitehead 2003a). These 2 different behaviors might help explain the different powers of the 2 GAMs in describing species distribution patterns. While the models performed well with the resident species, they lost power when dealing with the migratory species.

The 2 habitat models also suggested that habitat partitioning occurred amongst these 2 species in the Pelagos Sanctuary. In particular, peaks in the presence of Cuvier's beaked whale coincide with the habitat limit of the sperm whale and vice versa. This is particularly evident with depth, distance from the canyon axis and slope. While sperm whales and Cuvier's beaked whales may consume the same prey species, both whales are size-limited predators and only take a narrow range of prey relative to body size. As a consequence, they do not necessarily consume the same sizes of prey (MacLeod et al. 2006). The different habitat preferences of these 2 predators might then reflect differences in the distributions of prey species, indicating a reduction in niche overlap.

Acknowledgements. We thank the whale-watching operators for hosting students and researchers on board and making every possible effort to collect scientific data during whale-watching trips. Special thanks go to bluWest and, in particular, to Albert Sturlese, Barbara Nani and Marco Ballardini whose collaboration was essential to this study. The collaboration of Consorzio Liguria via Mare (in particular, Roberta Trucchi and Simone Scalise) allowed us to enlarge our study area. Thanks to the University of Genoa and, in particular, to Maurizio Würtz. This work would not have been possible without the enthusiasm of all the students and researchers who participated in the surveys on board the research vessel of the University of Genoa and who embarked as observers on whale-watching vessels. Many thanks go to Martin Desruisseaux and Michel Petit for the development of the database.

\section{LITERATURE CITED}

Allouche O, Tsoar A, Kadmon R (2006) Assessing the accuracy of species distribution models: prevalence, kappa and the true skill statistic (tss). J Appl Ecol 43:1223-1232

Ashe E, Noren DP, Williams R (2010) Animal behaviour and marine protected areas: incorporating behavioural data into the selection of marine protected areas for an endangered killer whale population. Anim Conserv 13: 196-203

Astraldi M, Gasparini GP, Sparnocchia S (1994) The seasonal and interannual variability in the LigurianProvencal basin. In: La Violette PE (ed) The seasonal and interannual variability of the western Mediterranean Sea, Vol 46. American Geophysical Union, Washington,
DC, p 93-113

Azzellino A, Airoldi S, Gaspari S, Patti P, Sturlese A (2001) Physical habitat of cetaceans along the continental slope of the western Ligurian Sea. In: Evans PGH, O'Boyle E (eds) Proc 15th Annu Conf European Cetacean Society. European Cetacean Society, Rome, p 239-243

- Azzellino A, Gaspari S, Airoldi S, Nani B (2008) Habitat use and preferences of cetaceans along the continental slope and the adjacent pelagic waters in the western Ligurian Sea. Deep-Sea Res I 55:296-323

Azzellino A, Lanfredi C, D'Amico A, Pavan G, Podestà M, Haun J (2011) Risk mapping for sensitive species to underwater anthropogenic sound emissions: model development and validation in two Mediterranean areas. Mar Pollut Bull 63:56-70

Azzellino A, Panigada S, Lanfredi C, Zanardelli M, Airoldi S, Notarbartolo Di Sciara G (2012) Predictive habitat models for managing marine areas: spatial and temporal distribution of marine mammals within the Pelagos Sanctuary (northwestern Mediterranean Sea). Ocean Coast Manag 67:63-74

Barlow J, Taylor B (2005) Estimates of sperm whale abundance in the northeastern temperate Pacific from a combined acoustic and visual survey. Mar Mamm Sci 21: 429-445

Blanco C, Raga JA (2000) Cephalopod prey of two Ziphius cavirostris (Cetacea) stranded on the western Mediterranean coast. J Mar Biol Assoc UK 80:381-382

Bonizzoni S, Furey NB, Pirotta E, Valavanis VD, Würsig B, Bearzi G (2013) Fish farming and its appeal to common bottlenose dolphins: modelling habitat use in a Mediterranean embayment. Aquat Conserv (in press), doi:10.1002/aqc.2401

Brotons L, Thuiller W, Araújo MB, Hirzel AH (2004) Presence-absence versus presence-only modelling methods for predicting bird habitat suitability. Ecography 27: 437-448

Cañadas AM, Sagarminaga R, García-Tiscar S (2002) Cetacean distribution related with depth and slope in the Mediterranean waters off southern Spain. Deep-Sea Res I 49:2053-2073

- Canals M, Puig P, de Madron XD, Heussner S, Palanques A, Fabres J (2006) Flushing submarine canyons. Nature 444:354-357

Certain G, Ridoux V, Van Canneyt O, Bretagnolle V (2008) Delphinid spatial distribution and abundance estimates over the shelf of the Bay of Biscay. ICES J Mar Sci 65: 656-666

Ciano JN, Huele R (2001) Photo-identification of sperm whales at Bleik Canyon, Norway. Mar Mamm Sci 17: 175-180

D'Amico A, Bergamasco A, Carniel S, Nacini E and others (2003) Qualitative correlation of marine mammals with physical and biological parameters in the Ligurian Sea. IEEE J Ocean Eng 28:29-43

De Leo FC, Smith CR, Rowden AA, Bowden DA, Clark MR (2010) Submarine canyons: hotspots of benthic biomass and productivity in the deep sea. Proc R Soc Lond B Biol Sci 277:2783-2792

Drouot V, Gannier A, Goold JC (2004) Diving and feeding behaviour of sperm whales (Physeter macrocephalus) in the northwestern Mediterranean Sea. Aquat Mamm 30:419-426

Dunn DC, Halpin PN (2009) Rugosity-based regional modeling of hard-bottom habitat. Mar Ecol Prog Ser 377:1-11 
Elith J, Graham CH, Anderson RP, Dudik M and others (2006) Novel methods improve prediction of species' distributions from occurrence data. Ecography 29:129-151

Evans PGH, Hammond PS (2004) Monitoring cetaceans in European waters. Mammal Rev 34:131-156

Falcone EA, Schorr GS, Douglas AB, Calambokidis J and others (2009) Sighting characteristics and photo-identification of Cuvier's beaked whales (Ziphius cavirostris) near San Clemente Island, California: a key area for beaked whales and the military? Mar Biol 156:2631-2640

Fielding AH, Bell JF (1997) A review of methods for the assessment of prediction errors in conservation presence/absence models. Environ Conserv 24:38-49

Frantzis A, Airoldi S, Notarbartolo Di Sciara G, Johnson C, Mazzariol S (2011) Inter-basin movements of Mediterranean sperm whales provide insight into their population structure and conservation. Deep-Sea Res I 58: 454-459

Fusco G, Manzella G, Cruzado A, Velasquez ZR and others (2003) Variability of mesoscale features in the Mediterranean Sea from XBT data analysis. Ann Geophys 21: 21-32

> Gannier A, Epinat J (2008) Cuvier's beaked whale distribution in the Mediterranean Sea: results from small boat surveys1996-2007. J Mar Biol Assoc UK 88:1245-1251

Gannier A, Praca E (2007) SST fronts and the summer sperm whale distribution in the north-west Mediterranean Sea. J Mar Biol Assoc UK 87:187-193

Gannier A, Drouot V, Goold JC (2002) Distribution and relative abundance of sperm whales in the Mediterranean Sea. Mar Ecol Prog Ser 243:281-293

Gannier A, Petiau E, Dulau V, Rendell L (2012) Foraging dives of sperm whales in the north-western Mediterranean Sea. J Mar Biol Assoc UK 92:1799-1808

Gordon JCD, Matthews JN, Panigada S, Gannier A, Borsani JF, Notarbartolo Di Sciara G (2000) Distribution and relative abundance of striped dolphins, and distribution of sperm whales in the Ligurian Sea cetacean sanctuary: result from a collaboration using acoustic monitoring techniques. J Cetacean Res Manag 2:27-36

Gowans S, Whitehead H, Arch JK, Hooker SK (2000) Population size and residency patterns of northern bottlenose whales (Hyperoodon ampullatus) using the Gully, Nova Scotia. J Cetacean Res Manag 2:201-210

Gregr EJ, Trites AW (2001) Predictions of critical habitat for five whale species in the waters of coastal British Columbia. Can J Fish Aquat Sci 58:1265-1285

> Gregr EJ, Nichol L, Ford JKB, Ellis G, Trites AW (2000) Migration and population structure of northeast Pacific whales off the coast of British Columbia: analysis of commercial whaling records from 1908-1967. Mar Mamm Sci 16:699-727

Gu W, Swihart RK (2004) Absent or undetected? Effects of non-detection of species occurrence on wildlife-habitat models. Biol Conserv 116:195-203

> Guisan A, Zimmermann NE (2000) Predictive habitat distribution models in ecology. Ecol Modell 135:147-186

> Hastie T, Tibshirani R (1986) Generalized additive models. Stat Sci 1:297-318

Heyning JE (1989) Cuvier's beaked whale Ziphius cavirostris g. Cuvier, 1823. In: Ridgway SH, Harrison RS (eds) Handbook of marine mammals, Vol 4. River dolphins and the larger toothed whales. Academic Press, London, p 289-308

Hirzel AH, Helfer V, Metral F (2001) Assessing habitat- suitability models with a virtual species. Ecol Modell 145: 111-121

Hooker SK, Whitehead H, Gowans S (1999) Marine protected area design and the spatial and temporal distribution of cetaceans in a submarine canyon. Conserv Biol 13:592-602

> Jaquet N (1996) How spatial and temporal scales influence understanding of sperm whale distribution: a review. Mammal Rev 26:51-65

Jenks GF (1967) The data model concept in statistical mapping. International Yearbook of Cartography 7:186-190

> Kenney RD, Winn HE (1987) Cetacean biomass densities near submarine canyons compared to adjacent shelf/ slope areas. Cont Shelf Res 7:107-114

Koslovsky S (2008) Wandering whale watches: the effectiveness of whale watches as a platform of opportunity for data collection. Duke University, Durham, NC

LMIU (Lloyd's Marine Intelligence Unit) (2008) Study of maritime traffic flows in the Mediterranean Sea. Regional Marine Pollution Emergency Response Centre for the Mediterranean Sea (REMPEC), Valetta

MacLeod CD, Mitchell G (2006) Key areas for beaked whales worldwide. J Cetacean Res Manag 7:309-322

MacLeod CD, Santos MB, López A, Pierce GJ (2006) Relative prey size consumption in toothed whales: implications for prey selection and level of specialisation. Mar Ecol Prog Ser 326:295-307

> MacLeod CD, Mandleberg L, Schweder C, Bannon SM, Pierce GJ (2008) A comparison of approaches for modelling the occurrence of marine animals. Hydrobiologia 612:21-32

Marra G, Wood SN (2012) Coverage properties of confidence intervals for generalized additive model components. Scand J Statist 39:53-74

> Migeon S, Cattaneo A, Hassoun V, Larroque C and others (2011) Morphology, distribution and origin of recent submarine landslides of the Ligurian margin (north-western Mediterranean): some insights into geohazard assessment. Mar Geophys Res 32:225-243

> Moulins A, Rosso M, Nani B, Würtz M (2007) Aspects of distribution of Cuvier's beaked whale (Ziphius cavirostris) in relation to topographic features in the Pelagos Sanctuary (north-western Mediterranean Sea). J Mar Biol Assoc UK 87:177-186

Moulins A, Rosso M, Ballardini M, Würtz M (2008) Partitioning of the Pelagos Sanctuary (north-western Mediterranean Sea) into hotspots and coldspots of cetacean distributions. J Mar Biol Assoc UK 88:1273-1281

Mussi B, Miragliuolo A, De Pippo T, Gambi MC, Chiota D (2001) The submarine canyon of Cuma (southern Tyrrhenian Sea, Italy), a cetacean key area to protect. In: Proc 15th Annu Conf European Cetacean Society. European Cetacean Society, Rome, p 168-182

Notarbartolo di Sciara G (2002) Cetacean species occurring in the Mediterranean and Black Seas. In: Notarbartolo di Sciara G (ed), Cetaceans of the Mediterranean and Black Seas: state of knowledge and conservation strategies. Section 3. A report to the ACCOBAMS Secretariat, Monaco

> Notarbartolo di Sciara G, Agardy T, Hyrenbach DK, Scovazzi T, Van Klaveren P (2008) The Pelagos Sanctuary for Mediterranean marine mammals. Aquatic Conserv 18: 367-391

Parker AJ (1982) The topographic relative moisture index: an approach to soil-moisture assessment in mountain 
terrain. Phys Geogr 3:160-168

Picco P, Cappelletti A, Sparnocchia S, Schiano ME, Pensieri S, Bozzano R (2010) Upper layer current variability in the central Ligurian Sea. Ocean Sci 6:825-836

Pirotta E, Matthiopoulos J, MacKenzie M, Scott-Hayward L, Rendell L (2011) Modelling sperm whale habitat preference: a novel approach combining transect and follow data. Mar Ecol Prog Ser 436:257-272

Praca E, Gannier A (2007) Ecological niche of three teuthophageous odontocetes in the northwestern Mediterranean Sea. Ocean Sci 4:785-815

Praca E, Gannier A, Das K, Laran S (2009) Modelling the habitat suitability of cetaceans: example of the sperm whale in the northwestern Mediterranean Sea. DeepSea Res I 56:648-657

Qin C, Zhu AX, Li B, Zhou C, Pei T, Shi X (2006) Fuzzy representation of spatial gradation of slope positions. In: Proc Int Symp on Terrain Analysis and Digital Terrain Modelling, Nanjing Normal University, Nanjing, p 9

Redfern JV, Ferguson MC, Becker EA, Hyrenbach DK and others (2006) Techniques for cetacean-habitat modeling. Mar Ecol Prog Ser 310:271-295

Reeves RR, Notarbartolo Di Sciara G (2006) The status and distribution of cetaceans in the Black Sea and Mediterranean Sea. The World Conservation Union (IUCN) Centre for Mediterranean Cooperation, Monaco

Rosso M, Ballardini M, Moulins A, Wurtz M (2011) Natural markings of Cuvier's beaked whale Ziphius cavirostris in the Mediterranean Sea. Afr J Mar Sci 33:45-57

Segurado P, Araújo MB (2004) An evaluation of methods for modelling species distributions. J Biogeogr 31:1555-1568

Sing T, Sander O, Beerenwinkel N, Lengauer T (2005) ROCR: visualizing classifier performance in R. Bioinformatics 21:3940-3941

Spyrakos E, Santos-Diniz TC, Martinez-Iglesias G, Torres-

Editorial responsibility: Yves Cherel,

Villiers-en-Bois, France
Palenzuela JM, Pierce GJ (2011) Spatiotemporal patterns of marine mammal distribution in coastal waters of Galicia, NW Spain. Hydrobiologia 670:87-109

> Stockwell DRB, Peterson AT (2002) Effects of sample size on accuracy of species distribution models. Ecol Modell 148: $1-13$

Torres LG, Read AJ, Halpin P (2008) Fine-scale habitat modeling of a top marine predator: Do prey data improve predictive capacity? Ecol Appl 18:1702-1717

Tyack PL, Johnson M, Aguilar Soto N, Sturlese A, Madsen PT (2006) Extreme diving of beaked whales. J Exp Biol 209:4238-4253

Waring GT, Hamazaki T, Sheehan D, Wood G, Baker S (2001) Characterization of beaked whale (Ziphiidae) and sperm whale (Physeter macrocephalus) summer habitat in shelf-edge and deeper waters off the northeast U.S. Mar Mamm Sci 17:703-717

Weiss A (2001) Topographic position and landforms analysis. Poster presentation, ESRI User Conference, San Diego, CA

Whitehead H (2003a) Differences in niche breadth among some teuthivorous mesopelagic marine mammals. Mar Mamm Sci 19:400-406

Whitehead H (2003b) Sperm whales: social evolution in the ocean. The University of Chicago Press, Chicago

- Whitehead H, Gowans S, Faucher A, McCarrey SW (1997) Population analysis of northern bottlenose whales in the Gully, Nova Scotia. Mar Mamm Sci 13:173-185

Wilds SPV (1996) Gradient analysis of the distribution of flowering dogwood (Cornus florida L.) and dogwood anthracnose (Discula destructive Redlin.) in western Great Smoky Mountains National Park. University of North Carolina, Chapel Hill, NC

Wood SN (2006) Generalized additive models: an introduction with R. Chapman \& Hall/CRC, Boca Raton, FL

Submitted: October 8, 2013; Accepted: May 7, 2014

Proofs received from author(s): July 23, 2014 